\title{
ANO1 wt Allele
}

National Cancer Institute

\section{Source}

National Cancer Institute. ANO1 wt Allele. NCI Thesaurus. Code C115174.

Human ANO1 wild-type allele is located in the vicinity of 11q13.3 and is approximately 111 $\mathrm{kb}$ in length. This allele, which encodes anoctamin-1 protein, is involved in the modulation of chloride transport. 